\title{
Photosynthetic Electron Transport Inhibition by 2-Substituted 4-Alkyl-6-benzylamino-1,3,5-triazines with Thylakoids from Wild-Type and Atrazine-Resistant Chenopodium album
}

\author{
Ruiko Okano ${ }^{\mathrm{a}}$, Aiko Ohki ${ }^{\mathrm{a}}$, Shinpei Ohki ${ }^{\mathrm{b}}$, Hitoshi Kohno ${ }^{\mathrm{a}}$, Jack J. S. van Rensen ${ }^{\mathrm{c}}$, \\ Peter Böger ${ }^{\mathrm{b}}$ and Ko Wakabayashi ${ }^{\mathrm{a}^{*}}$ \\ a Graduate School of Agricultural Science, Tamagawa University, Machida-shi, \\ Tokyo 194-8610, Japan. Fax: +81-42-739-8854. E-mail: kwaka@agr.tamagawa.ac.jp \\ b Lehrstuhl für Physiologie und Biochemie der Pflanzen, Universität Konstanz, \\ D-78457 Konstanz, Germany \\ c Graduate School of Experimental Plant Sciences, Wageningen University, Laboratory of \\ Plant Physiology, Arboretumlaan 4, 6703 BD Wageningen, The Netherlands \\ * Author for correspondence and reprint requests \\ Z. Naturforsch 57 c, 1009-1015 (2002); received July 3, 2002 \\ Electron Transport Inhibition, Herbicides, Novel Triazines \\ The effect of 2-benzylamino-1,3,5-triazines on photosynthetic electron transport (PET) was \\ measured with thylakoids isolated from atrazine-resistant, wild-type Chenopodium album, \\ and spinach to find novel 1,3,5-triazine herbicides bearing a strong PET inhibition. The PET \\ inhibition assay with Chenopodium (wild-type and resistant), yielded a resistance ratio (R/ \\ $\mathrm{W}=\mathrm{I}_{50}$ (resistant) $/ \mathrm{I}_{50}$ (wild-type)) of 324 for atrazine while for benzylamino-1,3,5-triazine \\ derivatives of diamino-1,3,5-triazines a $\mathrm{R} / \mathrm{W}$ of 11 to 160 was found. The compounds having \\ a benzylamino group at one of the amino groups in the diamino-1,3,5-triazines have a resis- \\ tant ratio down to one half to $1 / 30$ of the atrazine value. The average resistance ratio of 21 \\ benzylamino derivatives of monoamino-1,3,5-triazines was found to be about 4.0. The inhibi- \\ tion of 21 benzylamino-1,3,5-triazines assayed with atrazine-resistant Chenopodium thyla- \\ koids, indicated by $\mathrm{pI}_{50}(\mathrm{R})$-values, correlated well with the PET inhibition $\mathrm{pI}_{50}(\mathrm{~W})$ of wild- \\ type thylakoids from Chenopodium.
}

\section{Introduction}

The triazine herbicides like atrazine, simetryne and simazine, were introduced in the early $1950 \mathrm{~s}$ and contributed strongly to the general practice of chemical weed control (Esser et al., 1975). Nowadays, this type of herbicides including atrazine has been phased out for several reasons, such as appearance of herbicide-resistant weeds and environmental pollution. Kuboyama et al. (1998) have recently found novel 2-alkyl-4-benzylamino-6-trifluoromethyl-1,3,5-triazines, e.g. 2-(4-bromobenzylamino)-4-methyl-6-trifluoromethyl-1,3,5-triazine, which exhibit strong photosynthetic electron transport (PET) inhibition with thylakoids from spinach and atrazine-resistant Chenopodium al-

Abbreviations: PET, photosynthetic electron transport; $\mathrm{R}$, atrazine-resistant Chenopodium album; W, wild-type Chenopodium album; $\mathrm{pI}_{50}$, the logarithm of the reciprocal $\mathrm{I}_{50} ;$ PSII, Photosystem II; R/W, the ratio of the molar concentration producing $50 \%\left(\mathrm{I}_{50}\right)$ inhibition with resistant thylakoids over the wild-type ones. bum (Kuboyama et al., 1998, 1999; Ohki et al., 1999).

In this paper, PET inhibitory activities of a number of novel 1,3,5-triazines have been assayed using thylakoids isolated from both atrazine-resistant and wild-type of Chenopodium album, and compared with conventional diamino-1,3,5-triazine herbicides, such as atrazine and simazine.

\section{Materials and Methods}

\section{Chemicals}

All reaction products were purified through column chromatography and/or recrystallization, and their structures were confirmed by IR-, ${ }^{1} \mathrm{H}-\mathrm{NMR}$ and mass spectroscopy. Melting points (uncorrected) were measured with a Yanagimoto-Seisakusyo melting point apparatus. IR-spectra were recorded on a JASCO FT/IR-420 spectrophotometer and ${ }^{1} \mathrm{H}-\mathrm{NMR}$ spectra were measured in $\mathrm{CDCl}_{3}$ on a JEOL JNM-GX400 spectrometer at 
$400 \mathrm{MHz}$ using tetramethylsilane (TMS) as an internal standard.

The 1,3,5-triazines tested, excluding atrazine and simazine, were synthesized by a nucleophilic substitution reaction of corresponding chloro1,3,5-triazines or trichloromethyl-1,3,5-triazines with the appropriate amines according to our previous paper (Kuboyama et al., 1998). The physical and/or spectroscopical data of known benzylamino-1,3,5-triazines, i.e. 8, 12, 14, 26, 27, 28 \& 29 (Kuboyama et al., 1998) ; 9 (Ursprung, 1966) and 13, 22, 23, 24 \& 25 (Inoue et al., 2000) used in this study were reported elsewhere. For spectroscopical data of newly prepared benzylamino-1,3,5-triazines, see Table I. Typical procedures of the nucleophilic substitution reaction are given below.

Table I. Physical data of new amino-1,3,5-triazines synthesized for this study.
Synthesis of 2-chloro-4-(4-chlorobenzylamino)-6methyl-1,3,5-triazine (cpd. 10)

4-Chlorobenzylamine $(4.3 \mathrm{~g}, 0.03 \mathrm{~mol})$ was reacted with 2,4-dichloro-6-methyl-1,3,5-triazine (4.7 g, $0.03 \mathrm{~mol}$ ), prepared from cyanuric chloride and $\mathrm{CH}_{3} \mathrm{MgBr}$ according to Hirt et al. (1950), in the presence of triethylamine $(3.0 \mathrm{~g}, 0.03 \mathrm{~mol})$ in tetrahydrofuran $(120 \mathrm{ml})$. After stirring at room temperature for $22 \mathrm{~h}$, the mixture was concentrated under reduced pressure. The residue was washed with water and then recrystallized from $n$ hexane to give 2-chloro-4-(4-chlorobenzyl-

amino)-6-methyl-1,3,5-triazine as a white solid, $\mathrm{mp}$ $127-129^{\circ} \mathrm{C}$, yield $4.2 \mathrm{~g}(66.7 \%)$. IR $\lambda_{\text {MAX }}(\mathrm{KBr})$ $\mathrm{cm}^{-1}$ : 1531, 1568 (1,3,5-triazine ring). NMR $\delta_{\mathrm{H}}$ $\left(\mathrm{CDCl}_{3}\right)$ ppm : 2.39 and $2.46(3 \mathrm{H}$ in total, each $\mathrm{s}$, $\left.\mathrm{CH}_{3}\right), 4.63$ and $4.66(2 \mathrm{H}$ in total, each $\mathrm{d}, J=6.1 \mathrm{~Hz}$, $\left.\mathrm{NHCH}_{2}\right), 6.05$ and $6.34(1 \mathrm{H}$ in total, each br, $\mathrm{NH})$,

\begin{tabular}{|c|c|c|c|c|c|}
\hline No. & $\mathrm{R}_{1}$ & $\mathrm{X}$ & $\mathrm{mp}\left({ }^{\circ} \mathrm{C}\right)$ & $\begin{array}{c}\mathrm{IR} \\
\lambda_{\operatorname{MAX}}(\mathrm{KBr}) \mathrm{cm}^{-1}\end{array}$ & $\mathrm{NMR} \delta_{\mathrm{H}}\left(\mathrm{CDCl}_{3}, \mathrm{TMS}\right) \mathrm{ppm}$ \\
\hline 15 & $\mathrm{C}_{2} \mathrm{H}_{5}$ & $\mathrm{Cl}$ & $120-122$ & 1532 & 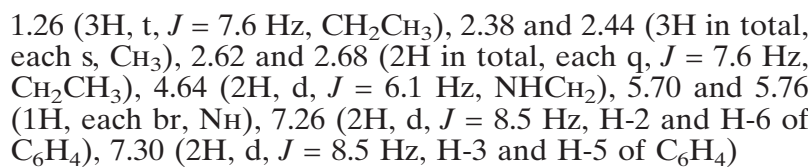 \\
\hline 17 & $\mathrm{C}_{3} \mathrm{H}_{7}-n$ & $\mathrm{Cl}$ & $117-118$ & 1537,1550 & 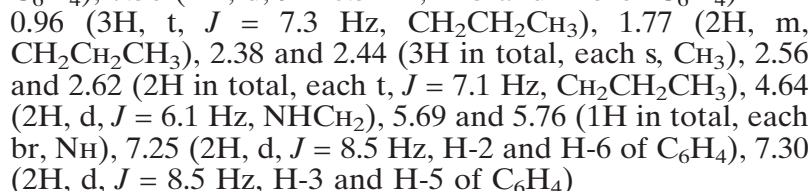 \\
\hline 18 & $\mathrm{C}_{3} \mathrm{H}_{7}-i$ & $\mathrm{H}$ & $60-63$ & 1518,1548 & $\begin{array}{l}1.26\left(6 \mathrm{H}, \mathrm{d}, J=6.6 \mathrm{~Hz}, \mathrm{CH}\left(\mathrm{CH}_{3}\right)_{2}\right), 2.38 \text { and } 2.44(3 \mathrm{H} \text { in } \\
\left.\text { total, each s, } \mathrm{CH}_{3}\right), 2.84\left(1 \mathrm{H}, \mathrm{m}, \mathrm{CH}\left(\mathrm{CH}_{3}\right)_{2}\right), 4.66(2 \mathrm{H}, \mathrm{s} \text {, } \\
\left.\mathrm{NHCH}_{2}\right), 5.58 \text { and } 5.67(1 \mathrm{H} \text { in total, each br, } \mathrm{NH}), 7.30(5 \mathrm{H} \text {, } \\
\left.\mathrm{m}, \mathrm{C}_{6} \mathrm{H}_{5}\right)\end{array}$ \\
\hline 19 & $\mathrm{C}_{3} \mathrm{H}_{7}-i$ & $\mathrm{Cl}$ & $104-105$ & 1556 & $\begin{array}{l}1.24\left(6 \mathrm{H}, \mathrm{d}, J=7.1 \mathrm{~Hz}, \mathrm{CH}\left(\mathrm{CH}_{3}\right)_{2}\right), 2.38 \text { and } 2.44(3 \mathrm{H} \text { in } \\
\left.\text { total, each s, } \mathrm{CH}_{3}\right), 2.86\left(1 \mathrm{H}, \mathrm{m}, \mathrm{CH}\left(\mathrm{CH}_{3}\right)_{2}\right), 4.63(2 \mathrm{H} \text { in } \\
\left.\text { total, d, } J=6.1 \mathrm{~Hz}, \mathrm{CH}_{2}\right), 5.61 \text { and } 5.74(1 \mathrm{H} \text { in total, each } \\
\text { br, } \mathrm{NH}), 7.26\left(2 \mathrm{H}, \mathrm{d}, J=8.5 \mathrm{~Hz}, \mathrm{H}-2 \text { and } \mathrm{H}-6 \text { of } \mathrm{C}_{6} \mathrm{H}_{4}\right), 7.30 \\
\left(2 \mathrm{H}, \mathrm{d}, J=8.5 \mathrm{~Hz}, \mathrm{H}-3 \text { and } \mathrm{H}-5 \text { of } \mathrm{C}_{6} \mathrm{H}_{4}\right)\end{array}$ \\
\hline 20 & $\mathrm{C}_{4} \mathrm{H}_{9}-t$ & $\mathrm{H}$ & $85-86$ & 1522,1555 & $\begin{array}{l}1.30\left(9 \mathrm{H}, \mathrm{s}, \mathrm{C}\left(\mathrm{CH}_{3}\right)_{3}\right), 2.39 \text { and } 2.45(3 \mathrm{H} \text { in total, each s, } \\
\left.\mathrm{CH}_{3}\right), 4.66\left(2 \mathrm{H} \text { in total, d, } J=5.6 \mathrm{~Hz}, \mathrm{NHCH}_{2}\right), 5.50 \text { and } \\
5.65(1 \mathrm{H} \text { in total, each br, } \mathrm{NH}), 7.31\left(5 \mathrm{H}, \mathrm{m}_{2} \mathrm{C}_{6} \mathrm{H}_{5}\right)\end{array}$ \\
\hline 30 & $\mathrm{CCl}_{3}$ & $\mathrm{Cl}$ & $137-139$ & 1539,1568 & $\begin{array}{l}2.53 \text { and } 2.59\left(3 \mathrm{H} \text { in total, each s, } \mathrm{CH}_{3}\right), 4.68 \text { and } 4.69(2 \mathrm{H} \\
\left.\text { in total, each d, } J=6.1 \mathrm{~Hz} \text { and } J=5.6 \mathrm{~Hz}, \mathrm{NHCH}_{2}\right), 6.00 \\
\text { and } 6.05(1 \mathrm{H} \text { in total, each br, } \mathrm{NH}), 7.31\left(4 \mathrm{H}, \mathrm{m}^{-} \mathrm{C}_{6} \mathrm{H}_{4}\right)\end{array}$ \\
\hline
\end{tabular}


7.24 and $7.25(2 \mathrm{H}$ in total, each d, $J=8.3 \mathrm{~Hz}, \mathrm{H}-2$ and $\mathrm{H}-6$ of the benzene ring), 7.31 and $7.32(2 \mathrm{H}$ in total, each $\mathrm{d}, J=8.3 \mathrm{~Hz}, \mathrm{H}-3$ and $\mathrm{H}-5$ of the benzene ring). MS: $m / z 268\left(\mathrm{M}^{+}\right)$. Intensities of isotope peaks of the compounds relative to $\mathrm{M}^{+}$-peak for $\mathrm{Cl}_{2}$ are found ; Calcd. (found): $\mathrm{M}^{+}$, $100 \%(100 \%) ; \mathrm{M}^{+}+2,65(66)$ and $\mathrm{M}^{+}+4,11(8)$. Isotope abundances were calculated according to ${ }^{35} \mathrm{Cl}:{ }^{37} \mathrm{Cl}=100.0: 32.5$.

Synthesis of 2-(4-chlorobenzylamino)-4-methoxy6-methyl-1,3,5-triazine (cpd. 11)

To a solution of sodium methoxide $(0.04 \mathrm{~g}, 1.74$ $\mathrm{mmol}$ ) in $30 \mathrm{ml}$ of methanol, 2-chloro-4-(4-chlorobenzylamino)-6-methyl-1,3,5-triazine $\quad(0.50 \mathrm{~g}$, $1.86 \mathrm{mmol}$ ) in $20 \mathrm{ml}$ of methanol was added at $0{ }^{\circ} \mathrm{C}$. After stirring at room temperature for $20 \mathrm{~h}$, the reaction mixture was concentrated under reduced pressure. The residue was washed with water and then recrystallized from $n$-hexane to give 2-(4-chlorobenzylamino)-4-methoxy-6-methyl-1,3,5-triazine as colorless crystal, mp 144$147^{\circ} \mathrm{C}$, yield $0.33 \mathrm{~g}(77.5 \%)$. IR $\lambda_{\mathrm{MAX}}(\mathrm{KBr}) \mathrm{cm}^{-1}$ : 1553,1573 (triazine ring). NMR $\delta_{\mathrm{H}}\left(\mathrm{CDCl}_{3}\right) \mathrm{ppm}$ : 2.32 and $2.40\left(3 \mathrm{H}\right.$ in total, each $\left.\mathrm{s}, \mathrm{CH}_{3}\right), 3.90$ and $3.93\left(3 \mathrm{H}\right.$ in total, each s, $\left.\mathrm{OCH}_{3}\right), 4.62$ and $4.65(2 \mathrm{H}$ in total, each $\mathrm{d}, J=6.1 \mathrm{~Hz}$ and $J=5.9 \mathrm{~Hz}$, $\left.\mathrm{NHCH}_{2}\right), 5.93$ and $6.22(1 \mathrm{H}$ in total, each br, $\mathrm{NH})$, $7.24(2 \mathrm{H}, \mathrm{d}, J=8.3 \mathrm{~Hz}, \mathrm{H}-2$ and $\mathrm{H}-6$ of the benzene ring), $7.30(2 \mathrm{H}, \mathrm{d}, J=8.3 \mathrm{~Hz}, \mathrm{H}-3$ and $\mathrm{H}-5$ of the benzene ring). MS: $m / z 264\left(\mathbf{M}^{+}\right)$.

Synthesis of 2-( tert-butyl)-4-(4-chlorobenzylamino)-6-methyl-1,3,5- triazine (cpd. 21)

4-Chlorobenzylamine $(1.2 \mathrm{~g}, 8.5 \mathrm{mmol})$ was reacted with 2-(4-tert-butyl)-4-methyl-6-trichloromethyl-1,3,5-triazine $(2.0 \mathrm{~g}, 7.5 \mathrm{mmol})$ in tetrahydrofuran $(10 \mathrm{ml})$. After stirring at room temperature for $45 \mathrm{~h}$, the mixture was concentrated under reduced pressure. The residue was washed with water and then purified by silica gel column chromatography using ethyl acetate : dichloromethane $=1: 10(\mathrm{v} / \mathrm{v})$ to give the 2-(4-chlorobenzylamino)-4-(tert-butyl)-6-methyl-1,3,5-triazine as colorless crystal, mp $79-81^{\circ} \mathrm{C}$, yield $0.8 \mathrm{~g}(36.7 \%)$. IR $\lambda_{\text {MAX }}(\mathrm{KBr}) \mathrm{cm}^{-1}: 1530,1555$ (triazine ring). NMR $\delta_{\mathrm{H}}\left(\mathrm{CDCl}_{3}\right)$ ppm: $1.28\left(9 \mathrm{H}, \mathrm{s}, \mathrm{C}\left(\mathrm{CH}_{3}\right)_{3}\right), 2.40$ and $2.44\left(3 \mathrm{H}\right.$ in total, each s, $\left.\mathrm{CH}_{3}\right), 4.62(2 \mathrm{H}, \mathrm{d}, J=$ $\left.6.1 \mathrm{~Hz}, \mathrm{NHCH}_{2}\right), 5.50$ and $5.63(1 \mathrm{H}$ in total, each br, $\mathrm{NH}), 7.28$ (4H, m, benzene ring). MS: $m / z 290\left(\mathrm{M}^{+}\right)$.

\section{Preparation of spinach thylakoids}

Thylakoids were prepared from spinach (Spinacia oleracea) leaves according to the method of Böger (1993). After removal of the midribs the leaves were homogenized in a cooking mixer using a medium containing $0.4 \mathrm{~m}$ sucrose, $50 \mathrm{~mm}$ Tricine (N-[2-hydroxy-1,1-bis(hydroxymethyl)ethyl]-glycine) $\left(\mathrm{pH} \mathrm{8.0),} 10 \mathrm{~mm} \mathrm{NaCl}\right.$ and $5 \mathrm{~mm} \mathrm{MgCl}_{2}$. The homogenate was filtered through eight layers of cheese cloth and centrifuged for $1 \mathrm{~min}$ at $4000 \times g$. The pellet was resuspended in the same medium for determination of PET inhibitory activity.

\section{Thylakoid preparation of atrazine-resistant and wild-type Chenopodium album}

For details of the isolation of thylakoids see van Rensen et al. (1977). Leaves from atrazine-resistant and wild-type Chenopodium were homogenized by a glass pestle using an isolation medium containing $0.4 \mathrm{~m}$ sorbitol, $20 \mathrm{~mm}$ Tricine- $\mathrm{NaOH}$ ( $\mathrm{pH} 7.8$ ), $10 \mathrm{~mm} \mathrm{NaCl}, 5$ mм $\mathrm{MgCl}_{2}, 2$ mм sodium ascorbate and $2 \mathrm{mg} / \mathrm{ml}$ bovine serum albumin. After squeezing the homogenate through eight layers of cheese cloth the chloroplasts were collected by centrifugation for $30 \mathrm{sec}$ at $500 \times g$ and $8 \mathrm{~min}$ $1000 \times g$, washed once in $50 \mathrm{~mm}$ sodium phosphate buffer ( $\mathrm{pH}$ 7.8) to obtain broken chloroplasts, and finally collected by centrifugation during $8 \mathrm{~min}$ at $1000 \times g$. The chlorophyll content was measured according to Bruinsma (1963), the chlorophyll concentration adjusted to $2 \mathrm{mg} \mathrm{Chl} / \mathrm{ml}$, and the thylakoids stored at $-80{ }^{\circ} \mathrm{C}$.

\section{Determination of PET-inhibitory activity with the oxygen electrode}

Photosynthetic electron transport activity was measured according to van Rensen et al. (1977; 1978). Oxygen evolution was measured at $25^{\circ} \mathrm{C}$ at saturating white light with a Gilson oxygraph provided with a Clark oxygen electrode. For measurement of photosystem (PS) II-dependent electron flow the isolated thylakoids were suspended in $2 \mathrm{ml}$ reaction medium containing $0.3 \mathrm{M}$ sorbitol, $50 \mathrm{~mm}$ Tricine- $\mathrm{NaOH}$ ( $\mathrm{pH} 7.6$ ), $5 \mathrm{~mm} \mathrm{MgCl}_{2}, 5 \mathrm{~mm}$ $\mathrm{NH}_{4} \mathrm{Cl}, 1 \mathrm{~mm}$ potassium ferricyanide and thyla- 
koids including $50 \mu \mathrm{g}$ chlorophyll. The inhibition is expressed as $\mathrm{pI}_{50}$ values, the negative logarithms of the molar concentration at which the compound produced a $50 \%$ inhibition.

\section{Results and Discussion}

Synthesis of benzylamino-1,3,5-triazines

The benzylamino-1,3,5-triazines assayed were readily synthesized by the nucleophilic amination reaction of 2,4-dichloro-6-methyl-1,3,5-triazine (compounds $\mathbf{9}$ and $\mathbf{1 0}$ in Table III, yield $67-93 \%$ ) or 2,4-dialkyl-6-trichloromethyl-1,3,5-triazines (compounds 12-30, yield 45-90\%). 2-(4-Chlorobenzylamino)-4-methyl-6-methoxy-1,3,5-triazine (11) was prepared by methoxylation of 2-chloro-4-(4chlorobenzylamino)-6-methyl-1,3,5-triazine (10) with sodium methoxide. The ${ }^{1} \mathrm{H}-\mathrm{NMR}$ spectra of 2-substituted-4-alkyl-6-benzylamino-1,3,5-triazines showed a set of resonance for the particular protons. For example, compound $\mathbf{1 0}$ exhibited two signals at $\delta 2.39$ and 2.46 for the 2-methyl protons, two signals at $\delta 4.63$ and 4.66 for the $\mathrm{CH}_{2}-$ $\mathrm{C}_{6} \mathrm{H}_{4} \mathrm{Cl}-4$ and two signals at $\delta 6.05$ and 6.34 for the $\mathrm{NH}_{\mathrm{H}}$ proton. This finding in ${ }^{1} \mathrm{H}-\mathrm{NMR}$ spectra of monoamino-1,3,5-triazines was already observed in our previous papers (Kuboyama et al., 1998; 1999; Inoue et al., 2000; Okano et al., 1993). The $\pi$-electron on the 1,3,5-triazine ring and the lone electron pair at the (benzyl)amino nitrogen are considered to conjugate each other to form a sort of molecular orbital, rendering the bond between C-6 and nitrogen a kind of partial double bond character. Accordingly, several sets of two resonances in ${ }^{1} \mathrm{H}-\mathrm{NMR}$ spectra can be observed due to a sort of syn-anti isomerism of the $\mathrm{C}-\mathrm{N}$ bond occurring only in the magnetic field.

\section{PET inhibition of diamino-1,3,5-triazines with Chenopodium thylakoids}

In a preliminary study, we examined the PET inhibitory activities of several diamino-1,3,5-triazines with thylakoids from both atrazine-resistant and wild-type Chenopodium album as well as from spinach. Results are shown in Table II.

The reference compounds, atrazine and simazine, exhibited strong PET inhibition $\left(\mathrm{pI}_{50}>6.00\right)$ with thylakoids from wild-type of Chenopodium album and spinach with a R/W-ratio of more than 300 , but only weak inhibition ( $\mathrm{pI}_{50}$ about 4 ) with thylakoids from atrazine-resistant Chenopodium.
Table II. PET inhibition by diamino-1,3,5-triazines with spinach and Chenopodium thylakoids.

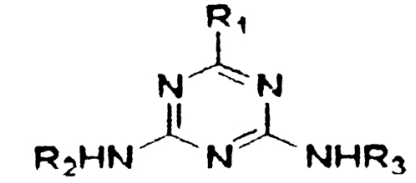

\begin{tabular}{|c|c|c|c|c|c|c|c|c|}
\hline \multirow{2}{*}{$\begin{array}{c}\text { Compounds } \\
\text { No. }\end{array}$} & \multirow[b]{2}{*}{$\mathrm{R}_{1}$} & \multirow[b]{2}{*}{$\mathrm{R}_{2}$} & \multirow[b]{2}{*}{$\mathrm{X}$} & \multirow[b]{2}{*}{$\mathrm{mp}\left[{ }^{\circ} \mathrm{C}\right]$} & \multicolumn{3}{|c|}{ Chenopodium album } & \multirow{2}{*}{$\frac{\text { Spinach }}{\mathrm{pI}_{50}(\mathrm{Sp})}$} \\
\hline & & & & & $\begin{array}{l}\text { Wild-type } \\
\text { pI }_{50} \text { (W) }\end{array}$ & $\begin{array}{l}\text { Resistant-type } \\
\mathrm{pI}_{50}(\mathrm{R})\end{array}$ & $\mathrm{R} / \mathrm{W}$ & \\
\hline Atrazine & $\mathrm{Cl}$ & $\mathrm{C}_{2} \mathrm{H}_{5}$ & $\mathrm{C}_{3} \mathrm{H}_{7}-i$ & $175-177$ & 6.72 & 4.21 & 324 & 6.73 \\
\hline Simazine & $\mathrm{Cl}$ & $\mathrm{C}_{2} \mathrm{H}_{5}$ & $\mathrm{C}_{2} \mathrm{H}_{5}$ & $225-227$ & 6.60 & 4.10 & 316 & 6.28 \\
\hline $1 * 1)$ & $\mathrm{CF}_{3}$ & $\mathrm{C}_{2} \mathrm{H}_{5}$ & $\mathrm{C}_{3} \mathrm{H}_{7}-i$ & $107-108$ & 6.74 & 4.18 & 363 & 5.99 \\
\hline $2 * 2)$ & $\mathrm{CF}_{3}$ & $\mathrm{C}_{2} \mathrm{H}_{5}$ & $\mathrm{CH}_{2} \mathrm{C}_{6} \mathrm{H}_{5}$ & $109-111$ & 6.94 & 4.72 & 166 & 7.14 \\
\hline $3 * 2)$ & $\mathrm{CF}_{3}$ & $\mathrm{C}_{3} \mathrm{H}_{7}-i$ & $\mathrm{CH}_{2} \mathrm{C}_{6} \mathrm{H}_{5}$ & oil & 6.80 & 4.59 & 162 & 6.51 \\
\hline $4 * 3)$ & $\mathrm{Cl}$ & $\mathrm{C}_{2} \mathrm{H}_{5}$ & $\mathrm{CH}_{2} \mathrm{C}_{6} \mathrm{H}_{5}$ & $185-189$ & 6.94 & 5.70 & 17.3 & 6.62 \\
\hline $5 * 3)$ & $\mathrm{Cl}$ & $\mathrm{C}_{3} \mathrm{H}_{7}-i$ & $\mathrm{CH}_{2} \mathrm{C}_{6} \mathrm{H}_{5}$ & $121-123$ & 6.36 & 5.26 & 12.6 & 6.35 \\
\hline $6 * 4)$ & $\mathrm{CH}_{3}$ & $\mathrm{C}_{2} \mathrm{H}_{5}$ & $\mathrm{CH}_{2} \mathrm{C}_{6} \mathrm{H}_{5}$ & $152-154$ & 5.33 & 4.06 & 18.6 & 4.57 \\
\hline $7 * 4)$ & $\mathrm{CH}_{3}$ & $\mathrm{C}_{3} \mathrm{H}_{7}-i$ & $\mathrm{CH}_{2} \mathrm{C}_{6} \mathrm{H}_{5}$ & $98-100$ & 5.05 & 4.00 & 11.2 & 4.71 \\
\hline
\end{tabular}

*1) Compound 1 was prepared from 2,4-bis(trichloromethyl)-6-trifluoromethyl-1,3,5-triazine according to Tsunoda et al. (1977).

*2) Compounds 2 and $\mathbf{3}$ were synthesized via amination of 2-benzylamino-4-trichloromethyl-6-trifluoromethyl1,3,5-triazine.

*3) Omokawa and Konnai (1990) have reported 7.09 and 6.66 as $\mathrm{pI}_{50}(\mathrm{Sp})$-values for compounds 4 and $\mathbf{5}$, respectively.

*4) Compounds 6 and 7 were prepared from 2-benzylamino-4-trichloromethyl-6-trifluoromethyl-1,3,5-triazine. 
In compound $\mathbf{1}$, the chlorine atom of atrazine is replaced by a $\mathrm{CF}_{3}$ group. It also exhibited strong PET inhibition $\left(\mathrm{pI}_{50}(\mathrm{~W})=6.74\right)$ with wild-type thylakoids, but only weak inhibition with the resistant ones $\left(\mathrm{pI}_{50}(\mathrm{R})=4.18\right)$ with the $\mathrm{R} / \mathrm{W}$ still around 300. Compounds $\mathbf{2}$ and $\mathbf{3}$, in which a benzylamino group was introduced for one amino group of compound $\mathbf{1}$, showed a $\mathrm{R} / \mathrm{W}$ ratio decreased to ca. 160, but kept a strong PET inhibitory activity $\left(\mathrm{pI}_{50}(\mathrm{~W})>6.80\right)$ with the wild-type thylakoids. Replacement of one N-alkyl of atrazine or simazine by a benzylamino group decreased the R/W-ratio remarkably to $12-17$, keeping, however, a strong PET inhibition with the wild-type thylakoids (see compounds $\mathbf{4}$ and $\mathbf{5}$ in Table II). Compounds $\mathbf{6}$ and $\mathbf{7}$ with the electrondonating $\mathrm{CH}_{3}$-group as the $\mathrm{R}_{1}$ substituent also exhibited a lower R/W-ratio (11-18) but PET inhibi- tion by these compounds was too weak to be discussed further. By these findings it can be concluded, that the 1,3,5-triazines with a benzylamino group bring about strong PET inhibition with the atrazine-resistant thylakoids of Chenopodium, resulting in a decreased $\mathrm{R} / \mathrm{W}$-ratio.

\section{PET inhibition of benzylamino-1,3,5-triazines with Chenopodium thylakoids}

Since introduction of a benzylamino group to the 1,3,5-triazine ring appeared to be useful for molecular design of strong PET inhibitors in atrazine-resistant Chenopodium, a number of benzylamino-1,3,5-triazines were synthesized and evaluated for PET inhibitory activities (Table III).

The resistance ratios of atrazine and simazine, conventional diamino-1,3,5-triazine herbicides,

Table III. PET inhibition by benzylamino-1,3,5-triazines with Chenopodium and spinach thylakoids.

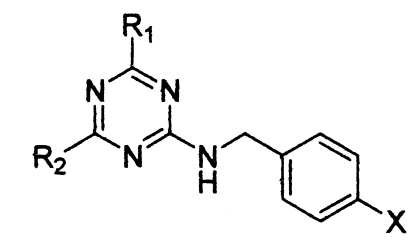

\begin{tabular}{|c|c|c|c|c|c|c|c|c|}
\hline \multirow[b]{2}{*}{ No. } & \multirow[b]{2}{*}{$\mathrm{R}_{1}$} & \multirow[b]{2}{*}{$\mathrm{R}_{2}$} & \multirow[b]{2}{*}{$\mathrm{X}$} & \multirow[b]{2}{*}{$\mathrm{mp}\left[{ }^{\circ} \mathrm{C}\right]$} & \multicolumn{3}{|c|}{ Chenopodium album } & \multirow{2}{*}{$\frac{\text { Spinach }}{\mathrm{pI}_{50}(\mathrm{Sp})}$} \\
\hline & & & & & $\begin{array}{l}\text { Wild-type } \\
\mathrm{pI}_{50}(\mathrm{~W})\end{array}$ & $\begin{array}{l}\text { Resistant-type } \\
\text { pI }_{50}(\mathrm{R})\end{array}$ & $\mathrm{R} / \mathrm{W}$ & \\
\hline 8 & $\mathrm{H}$ & $\mathrm{CH}_{3}$ & $\mathrm{H}$ & $74-75$ & $<4.00$ & $<4.00$ & - & $<4.00$ \\
\hline 9 & $\mathrm{Cl}$ & $\mathrm{CH}_{3}$ & $\mathrm{H}$ & $98-100$ & 5.24 & 4.38 & 7.3 & 5.33 \\
\hline 10 & $\mathrm{Cl}$ & $\mathrm{CH}_{3}$ & $\mathrm{Cl}$ & $127-129$ & 6.65 & 5.80 & 7.1 & 6.97 \\
\hline 11 & $\mathrm{OCH}_{3}$ & $\mathrm{CH}_{3}$ & $\mathrm{Cl}$ & $149-151$ & 6.28 & 5.21 & 11.7 & 6.09 \\
\hline 12 & $\mathrm{CH}_{3}$ & $\mathrm{CH}_{3}$ & $\mathrm{H}$ & $113-114$ & 5.32 & 5.34 & 1.0 & 4.19 \\
\hline 13 & $\mathrm{CH}_{3}$ & $\mathrm{CH}_{3}$ & $\mathrm{Cl}$ & $133-134$ & 5.47 & 4.75 & 5.2 & 5.78 \\
\hline 14 & $\mathrm{C}_{2} \mathrm{H}_{5}$ & $\mathrm{CH}_{3}$ & $\mathrm{H}$ & $71-73$ & 5.25 & 5.13 & 1.3 & 5.16 \\
\hline 15 & $\mathrm{C}_{2} \mathrm{H}_{5}$ & $\mathrm{CH}_{3}$ & $\mathrm{Cl}$ & $120-122$ & 6.64 & 6.44 & 1.3 & 6.45 \\
\hline 16 & $\mathrm{C}_{3} \mathrm{H}_{7}-n$ & $\mathrm{CH}_{3}$ & $\mathrm{H}$ & $47-49$ & 5.38 & 5.07 & 2.0 & 4.81 \\
\hline 17 & $\mathrm{C}_{3} \mathrm{H}_{7}-n$ & $\mathrm{CH}_{3}$ & $\mathrm{Cl}$ & $117-118$ & 7.22 & 6.52 & 5.0 & 7.05 \\
\hline 18 & $\mathrm{C}_{3} \mathrm{H}_{7}-i$ & $\mathrm{CH}_{3}$ & $\mathrm{H}$ & $60-63$ & 6.05 & 5.60 & 2.9 & 5.65 \\
\hline 19 & $\mathrm{C}_{3} \mathrm{H}_{7}-i$ & $\mathrm{CH}_{3}$ & $\mathrm{Cl}$ & $104-105$ & 7.30 & 6.92 & 2.4 & 7.31 \\
\hline 20 & $\mathrm{C}_{4} \mathrm{H}_{9}-t$ & $\mathrm{CH}_{3}$ & $\mathrm{H}$ & $85-86$ & 6.55 & 5.85 & 5.2 & 5.99 \\
\hline 21 & $\mathrm{C}_{4} \mathrm{H}_{9}-t$ & $\mathrm{CH}_{3}$ & $\mathrm{Cl}$ & $79-81$ & 7.13 & 6.57 & 3.6 & 6.86 \\
\hline 22 & $\mathrm{CH}_{2} \mathrm{~F}$ & $\mathrm{CH}_{3}$ & $\mathrm{H}$ & $83-84$ & 4.43 & $<4.00$ & - & 4.98 \\
\hline 23 & $\mathrm{CH}_{2} \mathrm{~F}$ & $\mathrm{CH}_{3}$ & $\mathrm{Cl}$ & $110-112$ & 5.64 & 4.80 & 7.0 & 6.15 \\
\hline 24 & $\mathrm{CHF}_{2}$ & $\mathrm{CH}_{3}$ & $\mathrm{H}$ & $62-63$ & 5.21 & 4.82 & 2.5 & 5.63 \\
\hline 25 & $\mathrm{CHF}_{2}$ & $\mathrm{CH}_{3}$ & $\mathrm{Cl}$ & $90-91$ & 6.18 & 5.82 & 2.3 & 6.62 \\
\hline 26 & $\mathrm{CF}_{3}$ & $\mathrm{CH}_{3}$ & $\mathrm{H}$ & $57-59$ & 7.03 & 6.61 & 2.6 & 6.85 \\
\hline 27 & $\mathrm{CF}_{3}$ & $\mathrm{CH}_{3}$ & $\mathrm{Cl}$ & $74-76$ & 7.19 & 6.93 & 1.8 & 6.98 \\
\hline 28 & $\mathrm{CF}_{3}$ & $\mathrm{CH}_{3}$ & $\mathrm{Br}$ & $99-100$ & 7.34 & 7.43 & 0.8 & 6.94 \\
\hline 29 & $\mathrm{CF}_{3}$ & $\mathrm{C}_{2} \mathrm{H}_{5}$ & $\mathrm{H}$ & $44-46$ & 5.86 & 5.40 & 2.9 & 5.64 \\
\hline 30 & $\mathrm{CCl}_{3}$ & $\mathrm{CH}_{3}$ & $\mathrm{Cl}$ & $137-139$ & 7.08 & 6.55 & 3.4 & 7.26 \\
\hline Atrazine & - & - & - & $175-177$ & 6.72 & 4.21 & 324 & 6.73 \\
\hline
\end{tabular}

The $\mathrm{pI}_{50}(\mathrm{Sp})$ - values of compounds $\mathbf{8}, \mathbf{1 2}, \mathbf{1 4}, \mathbf{1 6}$ and $\mathbf{2 2 - 2 9}$, and $\mathrm{pI}_{50}(\mathrm{R})$ and $\mathrm{pI}_{50}(\mathrm{~W})$ - values of compounds 22-28 were reported briefly in refs. Kuboyama et al. (1998; 1999), Inoue et al. (2000) and Kohno et al. (2000). 
were 324 and 316, respectively (Table II). The mean resistance ratio of the 21 benzylamino-1,3,5triazines was calculated to be about 4.0, indicative of almost no cross-resistance between atrazine and the benzylamino-1,3,5-triazines assayed (Table III). The R/W-ratios show, however, a range of deviation $(0.8-11.7)$ for individual benzylamino1,3,5-triazines. The ratios were $1.0-11.7$ for the benzylamino-1,3,5-triazines bearing electron-donating groups at $\mathrm{R}_{1}$, i.e. compounds (11-21), and were found $0.8-7.3$ for the benzylamino-1,3,5-triazines with electron-withdrawing groups at $\mathrm{R}_{1}$, like compounds $(\mathbf{9}, \mathbf{1 0}, \mathbf{2 2 - 3 0})$. The benzylamino1,3,5-triazines having a $\mathrm{CF}_{3}$-group at $\mathrm{R}_{1}$, namely compounds 26, 27 and 28, were very active with both their $\mathrm{pI}_{50}(\mathrm{R})$ and $\mathrm{pI}_{50}(\mathrm{~W})$-values over 6.60. This finding may corroborate our previous observation (Kuboyama et al., 1998) that 2-benzylamino-4-methyl-6-trifluoromethyl-1,3,5-triazines are not only active against atrazine-resistant weeds, but also herbicidal for normal weeds. Introduction of halogen $(\mathrm{Cl}$ or $\mathrm{Br})$ at 4-position of the benzene ring resulted in a 2-3 fold increase of PET inhibition, a finding also confirming our results from pot tests (Kuboyama et al., 1998).
PET inhibition of 21 benzylamino-1,3,5-triazines (9-21, 23-30) with atrazine-resistant Chenopodium thylakoids, indicated by $\mathrm{pI}_{50}(\mathrm{R})$-values, correlated well with their PET inhibition $\left(\mathrm{pI}_{50}\right.$ (W)) in thylakoids of wild-type of Chenopodium, as shown by the regression line and equation of Fig. 1A. Furthermore, the PET inhibition $\left(\mathrm{pI}_{50}\right.$ (W)) of these benzylamino-1,3,5-triazines with wild-type Chenopodium thylakoids correlated fairly well with their PET inhibitory activities $\left(\mathrm{pI}_{50}\right.$ $(\mathrm{Sp})$ ) in spinach thylakoids, as shown by the equation of Fig. 1B. Using the $\mathrm{pI}_{50}(\mathrm{Sp})$-value of newly designed benzylamino-1,3,5-triazines and equations of Fig. 1, A, B, we can now predict the $\mathrm{pI}_{50}$ $(\mathrm{W})$ and $\mathrm{pI}_{50}(\mathrm{R})$-values of the compounds.

According to the inhibition assay of this study, conventional diamino-type 1,3,5-triazines, such as atrazine and simazine, exhibited weak PET inhibitory activities with thylakoids from atrazine-resistant Chenopodium, but benzylamino-1,3,5-triazines revealed a strong PET inhibition with the resistant thylakoids. In atrazine-resistant Chenopodium (Bettini et al., 1987), the serine residue no. 264, a constituent amino acid of D1-protein of photosystem II, is mutated to glycine, thus atrazine cannot bind to the D1-protein (Hirschberg et al., 1984). 2-Benzylamino-4-methyl-6-trifluoromethyl-1,3,5-triazines are assumed to bind at the same niche of the D1-protein as atrazine, but in-

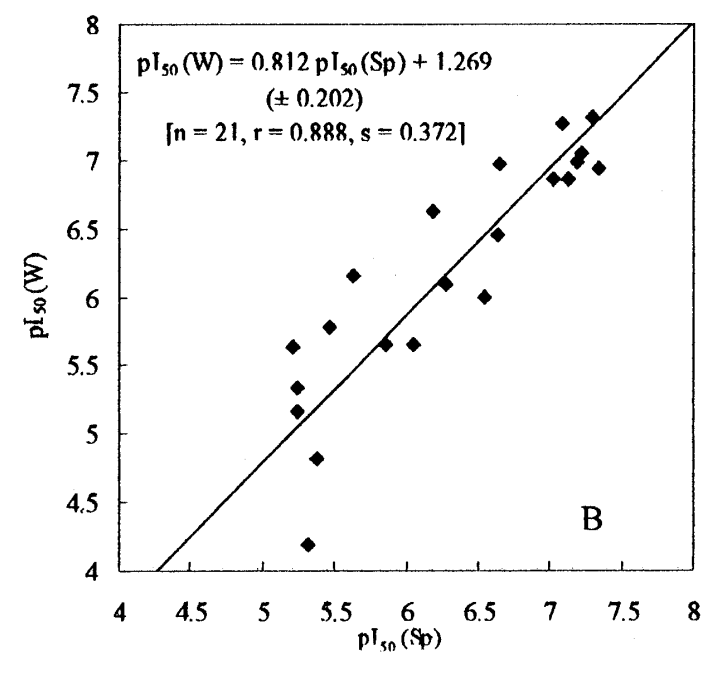

Fig. 1. Correlation of PET inhibitory activities of 21 benzylamino-1,3,5-triazines with Chenopodium and spinach thylakoids. (A): $\mathrm{pI}_{50}(\mathrm{~W})$ of wild-type $v s . \mathrm{pI}_{50}(\mathrm{R})$ of resistant Chenopodium, $(\mathrm{B}): \mathrm{pI}_{50}(\mathrm{Sp})$ of spinach $v s . \mathrm{pI}_{50}(\mathrm{~W})$ wild-type Chenopodium. 
teract with different amino acid residues, since the mutation of Ser 264 to glycine has no effect on binding of the novel triazines. To study the accurate binding niche of the benzylamino-1,3,5-triazines, replacement assays according to Ohki et al. (1999) using both $\left[{ }^{14} \mathrm{C}\right]$-atrazine and $\left[{ }^{14} \mathrm{C}\right]$-2-benzylamino-4-methyl-6-trifluoromethyl-1,3,5-triazine are now under way with resistant- and wild-type Chenopodium.

\section{Acknowledgments}

The authors express their thanks to Drs. Yukiharu Sato and Hiroshi Hori, both Tamagawa University, for invaluable help and discussion throughout this work. They are grateful to Dr. Yoshiko Miyamoto, Kitasato University, for interpretation of NMR spectra of the compounds.
Bettini P., McNally S., Sevignac M., Darmency H., Gasquez J. and Dron M. (1987), Atrazine resistance in Chenopodium album - low and high levels of resistance to the herbicide are related to the same chloroplast psbA gene for mutation. Plant Physiol. 84, 1442-1446.

Böger P. (1993), Inhibition of the photosynthetic electron transport system. In: Target Assays for Modern Herbicides and Related Phytotoxic Compounds (P. Böger and G. Sandmann, eds.). Lewis Publ., Boca Raton, FL, pp. 83-91.

Bruinsma J. (1963), The quantitative analysis of chlorophylls $\mathrm{a}$ and $\mathrm{b}$ in plant extracts. Photochem. Photobiol. 2, 214-249.

Esser H. O., Dupuis G., Ebert E., Marco G. and Vogel C. (1975), s-Triazines. In: Herbicides, Chemistry, Degradation, and Mode of Action (P. C. Kearney and D. D. Kaufman, eds.). Vol. 1, Marcel Dekker Inc., New York, pp. 129-208.

Hirschberg J., Bleeker A., Kyle D. J., McIntosh L. and Arntzen C. J. (1984), The molecular basis of triazine herbicide resistance in higher-plant chloroplasts. Z. Naturforsch. 39c, $412-420$.

Hirt R., Nidecker H. and Berchtold R. (1950), Syntheses with cyanuryl chloride. Helv. Chim. Acta. 33, 13651369.

Inoue H., Ohki S., Kotaka E., Kuboyama N., Ohki A., Koizumi K., Kohno H., Böger P. and Wakabayashi K. (2000), Photosynthetic electron transport inhibitory and herbicidal activities of 2-(fluorinatedmethyl)-4benzylamino-6-methyl-1,3,5-triazines. J. Pestic. Sci. 25, 101-106.

Kohno H., Ohki A., Ohki S., Koizumi K., van den Noort M. E., Rodrigues G. C., van Rensen J. J. S. and Wakabayashi K. (2000), Low resistance against novel 2-benzylamino-1,3,5-triazine herbicides in atrazine-resistant Chenopodium album plants. Photosynth. Res. 65, $115-120$.

Kuboyama N., Koizumi K., Ohki S. and Wakabayashi K. (1998), Synthesis and herbicidal activity of 2-ben- zylamino-4-methyl-6-trifluoromethyl-1,3,5-triazine derivatives. J. Pestic. Sci. 23, 268-274.

Kuboyama N., Koizumi K., Ohki A., Ohki S., Kohno H. and Wakabayashi K. (1999), Photosynthetic electron transport inhibitory activity of 2-arylamino-4-methyl6-trifluoro-methyl-1,3,5-triazine derivatives. J. Pestic. Sci. 24, 138-142.

Ohki A., Kuboyama N., Koizumi K., Tanaka A., Sato Y., Kohno H., Böger P. and Wakabayashi K. (1999), Mode of action of novel 2-(benzylamino)-4-methyl-6(trifluoromethyl)-1,3,5-triazine herbicides: inhibition photosynthetic electron transport and binding studies. J. Agric. Food. Chem. 47 (10), 4398-4402.

Okano N., Murakami M., Miyamoto Y., Koizumi K., Ogawa H. and Wakabayashi K. (1993), Synthesis and structure activity relationship of newer trichloromethyl-1,3,5-triazine nitrification inhibitors. J. Pestic. Sci. 18, 361-368.

Omokawa H. and Konnai M. (1990), PSII inhibitory activity of 2,4-diamino-6-chloro-s-triazines with a chiral sec-butyl and/or $\alpha$-methylbenzyl group. Agric. Biol. Chem. 54, 2373-2378.

Tsunoda M., Tobe A., Omata K. and Shirasaka T. (Mitsubishi Chem. Ind., Ltd.) (1977), Jpn. Kokai Tokkyo Koho JP 52-83582.

Ursprung J. J. (Upjohn Company) (1966), U. S. Patent 3270015.

van Rensen J. J. S., van der Vet W. and van Vliet W. P. A. (1977), Inhibition and uncoupling of electron transport in isolated chloroplasts by the herbicide 4,6-dinitro-o-cresol. Photochem. Photobiol. 25, 579-583.

van Rensen J. J. S., Wong D. and Govindjee (1978), Characterization of the inhibition of photosynthetic electron transport in pea chloroplasts by the herbicide 4,6-dinitro-o-cresol by comparative studies with 3-(3,4-dichlorophenyl)-1,1-dimethylurea. Z. Naturforsch. 33 c, $413-420$. 